\title{
National Competitiveness for Welfare: The Solution or an Illusion?
}

\author{
Yassine Ounnabi and Lalla Latifa Alaoui
}

\begin{abstract}
The aim of this paper is to analyze the theoretical foundations of the national competitiveness concept from the economic perspective. National competitiveness does not seem to be a natural fit with economic theory. Classical economic authors usually discuss either complementary or competing specializations between countries, and competition is usually addressed at the level of manufactures or industries. In this paper, however, I show that key ingredients of the modern national competitiveness concept already exist in classical economics. Modern conceptions of competitiveness develop it in several approaches and levels, and link it with social goals as living standards. It is this link that we try in this paper to analyze the theoretical foundations. Finally, this paper addresses the principal modern conceptualizations of competitiveness by putting an emphasis on the national level.
\end{abstract}

Index Terms-Competition, Living standards, National competitiveness, Specializations.

\section{INTRODUCTION}

In a global world characterized by an intensity of exchanges, every country is expected to be enhancing its capacity to benefit as much as possible from the dynamics of the international trade. These dynamics are summarized in four trends: the economic rise of developing and emerging economies; the growing integration into the global economy; the rising prices of agricultural goods and natural resources since 2000, and the increasing interdependence of the world economy [1].

In this context, a question has often been asked in academic and political spectrums: how can a nation perform in international trade, while also benefiting from it especially in terms of an enhancement of the living standards?

This question is not a new one, and a specific answer to this question, a "successful" one, rests on the assumption that a country has to be competitive, or to have a certain degree of competitiveness, to succeed in world markets and benefit from it, and, accordingly, to enhance its living standards. This is the assumption that this paper tries to apply to the theoretical foundation.

Competitiveness is a multi-approaches concept. It can be analyzed on many levels and under different approaches. When this concept was defined at the firm and industry levels, it sounded reasonable, and the principal actor in the competitiveness game was the firm. But, when this concept

Manuscript received April 15, 2016; revised December 8, 2016.

Yassine Ounnabi is with the Office of Budget in the Moroccan Department of the Treasury in Rabat, Morocco (e-mail: yassineounnabi@gmail.com).

Lalla Latifa Alaoui is with University of Rabat-Souissi, Morocco (e-mail: alaoouila@gmail.com). was applied to the national level, it becomes misunderstood and ambiguous, especially when its precursors define and link the competing power of a country with its living standards.

Thus, I first present how classical economics authors approached the competitiveness concept (Section II). The debate around the national competitiveness concept and its theoretical link with living standards are then discussed in Section III. Finally, Section IV summarizes and provides the conclusions to the article.

\section{COMPETITIVENESS IN THE CLASSICAL ECONOMIC THEORY: FUNDAMENTALS}

In this section, we will revisit the fundamentals and draw on interesting materials from the four giants of the classical economy: Adam Smith, David Ricardo, Karl Marx and John Stuart Mill. The objective is to know how they approached competitiveness, especially on the national level.

\section{A. Adam Smith: Competitiveness in the Inquiry}

In his inquiry, the wealth of nations (WN hereafter), Adam Smith set two benefits of foreign trade for countries [2]:

"It carries out that surplus part of the produce of their land and labour for which there is no demand among them, and brings back in return for it something else for which there is a demand. It gives a value to their superfluities, by exchanging them for something else, which may satisfy a part of their wants, and increase their enjoyments" (WN, book 4, chapter 1, p. 338).

Nonetheless, for the Godfather of economics, it is the home trade which is the most important in terms of wealth and employment in the nation [3]:

"The inland or home trade, the most important of all, the trade in which an equal capital affords the greatest revenue, and creates the greatest employment to the people of the country, was considered as subsidiary only to foreign trade" (WN, Book 4, Chapter 1, p. 341).

Thus, taking into account this vision, the choice made by many authors to set Smith's theory as their first starting point to the competitiveness theory is wrong. Also, though Smith emphasized the complementarity between nations and not their competition, why many authors of competitiveness set him as their first poor link in the chain of national competitiveness theories? Perhaps, because Smith used many times in his inquiry the competition between countries [4]:

"But though the poor country, notwithstanding the inferiority of its cultivation, can, in some measure, rival the rich in the cheapness and goodness of its corn, it can pretend to no such competition in its manufactures; at least if those manufactures suit the soil, climate, and situation of the rich 
country" (WN, Book 1, Chapter 1, p. 66).

This statement can entice the reader to think that Smith used the national scale in his description of economic rivalry between nations. But, for him, competition is among manufactures and farmers of these countries. Also, the criterion of success of the manufactures or farmers may be explained by natural advantages, or by the degree of productivity of the labour in the nation. And finally, productivity is increased by three factors: dexterity of laborers, the time economy in labour and the invention of machines [5].

So, it is easy to notice that Smith's inquiry hasn't been well exploited by the authors of the competitiveness theories, who reduced him to just two words, "Absolute advantage" - a concept that even he did not actually define, and that his theory was therefore "misused" by them [6].

\section{B. David Ricardo: You Don'T Need to Be Competitive, Let the Others Be}

In his Principles of Political Economy and Taxation (1817), David Ricardo introduced other advantages of foreign trade for nations [7]:

"The foreign trade increases the amount and the variety of objects on which revenue may be expended, and affords, by the abundance and cheapness of commodities, incentives to saving and to the accumulation of capital" (Principles, Chapter 7).

We can therefore that affordability of a product is a key determinant in its consummation.

The famous example of Ricardo of wine and cloth, comparing Portugal to England seems to be an application of the concept at the country level in comparing two countries. But in fact, as we can see in his chapter on foreign trade, he compared the cost of production between the exchangeable commodities produced by manufactures of England and a farmer of Portugal. Also, he explained that the two countries can benefit notwithstanding that Portugal has lower costs in two commodities, taking thus in account opportunity costs of exchanges. As Smith had mentioned before, Ricardo also mentioned adaptation between the commodities produced in a nation and its natural or artificial advantages. Also, he stressed the impact of innovation in production process on the cost and the price of commodities.

\section{John Stuart Mill: the Important Is Imports}

As Smith, for John Stuart Mill, economic advantages of foreign trade reside in the imports rather than the exports. For him, "the utility of trade does not consist in the large fortunes which are made by merchants [8]. For him, the nation derives economic benefit from foreign trade and enhances its national wealth by importing commodities at a lower cost than the home cost. Also, he considered the theory which set the exports as the main objective of foreign trade as vulgar one [9]. Also, the most important advantages of foreign trade are the intellectual and the moral advantages of it: commerce enables nations to communicate. And here, he made a great contribution to the nation's competition theory, even, if it is likely he never heard about it. He states that the communication between nations was always a source of progress of nations, and "there is no nation which does not need to borrow from others, not merely particular arts or practices, but essential points of character in which its own type is inferior" [9] (JSM Principles, Book III, Chapter XVII).

Finally, in our competitiveness inquiry, JSM has many things to say. When he compared French and English manufactures, he analyzed their competition in terms of a comparative cheapness of wages between the two countries, the goodness and cheapness of material, the machinery, and others immaterial elements as the taste, ingenuity and enterprise [9].

\section{Karl Marx: Exports, a Question of Life and Death}

For the Godfather of socialists, Karl Marx refutes the idea that free trade creates an international division of labour that assigns to each country a production in harmony with its natural advantages [10]. For instance, he gave an example of the East Indies, where originally coffee and sugar were not produced. It is through colonization that these products were introduced into the Indies.

Marx explained how England adopted the doctrine of free trade after applying its protective policy. In order to expand the market of its manufactures, England adopted the free-trade policy, and thus, the exports of manufactures goods became indeed "a question of life and death" to this country: when home market is saturated, exports became the only way to expand production and markets.

In the introduction of Marx's speech of 1848 on the question of free trade, Frederick Engels compared the manufactures of England, France and Germany [11]. He explained the unmatched expansion of British manufactures and commerce between 1848 and 1866, among others, by the removal of the protective duties and the victory of the steam engine over all other means of transport. British manufactures benefited from the invention of steam the engine and seemed to leave their foreign competitors, with manual labor-focused industries, far behind. Also, he presented Germany as an example or favorable technical and institutional factors to the development of competitive manufactures or industries. Thus, after a complete transition from manual labor to machinery, and assisted by a favorable political and institutional context, such as the establishment of a strong central government and the standardization of the laws regulating trade, Germany became the second commercial nation in the world next to Great Britain and its manufactures became principal competitors to those of England. Finally, Engels presents France as a nation which has the supremacy in all articles of luxury and taste. But, no advantage is sustainable in light of innovation.

\section{COMPETITIVENESS FOR WELLBEING: THE SOLUTION OR THE AN ILLUSION?}

If economic classical theories gave the basic foundations of the competitiveness as the competitiveness of companies based on factors as the goodness (quality) of the product and its cheapness (Cost or price), the skills and ingenuity of labour, the innovation and institutions, modern authors of competitiveness have adapted and continue to adapt this concept on many other levels, e.g. the firm, the industry, the 
city, the region, the nation and link it with several economic and social objectives as wellbeing and social cohesion.

Since the late 1970's, the concept of national competitiveness has gained largely on the political, the business and the intellectual spectrums [12]. Thus, we support to the development of the national competitiveness concept under several approaches [13]. For instance, the macroeconomic approach of competitiveness analyzes how the monetary and the exchange rate policy can raises welfare of a country by promoting its international competitiveness [14]. The business strategy approach of competitiveness emphasized puts the strategy of firm in the center of analysis. The ambassador of this approach is of course Michael Porter. Finally, the technology and innovation approach stress on the role of knowledge and innovation in competing power of firms.

It is important to notice at this stage that the majority of definition of competitiveness define it through its determinants and don't define competitiveness itself per se. Also, the micro and the macro conception of competitiveness were developed at the same time, but, the two conceptions have been mixed to give us the modern definition of national competitiveness that many international organizations have adopted to set their own measures and applications of competitiveness.

To understand the national definition of competitiveness, it is important to set it in its historical context of development. First of all, the national competitiveness debate was launched in the field of foreign trade. Since the mid 1980's, in the United States, this debate was initiated in the context of US foreign trade deficit. This situation was attributed by many authors, such as Laura D'andrea Tyson by a long-run competitiveness problem [15]. Thus, with stressing the negative social impact of the erosion of US shares in world exports markets on the US standard of living, she used one of most basic popular definitions of national competitiveness developed in the beginning of the 1980's [15],: "the ability to compete effectively in world markets while simultaneously raising real incomes", and she defined it later [16] as "the ability of a nation to produce goods and services that meet the test of international markets while the citizens in this nation enjoy a living standards that is both rising and sustainable". We can sum up her vision of national competitiveness in two points: the first, that public strategic policy is a determinant in stimulating and creating national advantage. By adopting policies targeted to promote research and development, technologies diffusion among user industries, labor quality and flexibility, industrial investment, etc, the government can help significantly the private sector to develop its international competitiveness and, by deduction, the national living standards. The second point, building on the first, is that competitive advantage of a nation is created by the interaction of government policies and business strategies.

Laura's vision of national competitiveness gave a central role to government policies in enhancing the competitiveness of the private sector. Thus, national competitiveness became the "responsibility" of public and private sectors. Also, it can be set as the objective of a national teaming, empowered by industry, government and universities [17].

Paul R. Krugman, Georges N. Hatsopoulos and Lawrence
H. Summers criticized this vision since 1988. For them, the long-run competitiveness of the United States is caused by "low saving rates, high costs of capital, and the resulting inadequate level of both visible and invisible investment" [18]. They illustrated the weak foundation of the necessarily positive relation between the trade balance and rising living standards: the living standards can be enhanced through increasing trade deficits and the later can be achieved through a declining living standards. So, as a result, they linked the competitiveness of the US economy to its ability in the long run to maintain a rate of growth in living standards higher than that of other industrial countries. Thus, they link the increasing living standards to productivity rather than trade performance. To put it other words, it is the rising productivity which can enhance the living standards and not the international competitiveness of the national firms. Also, the authors explained the supremacy of the United States at the end of the 1960's by its advantage over competitor nations in both innovation and converting ideas into marketable products. This supremacy enabled the United States to produce and export differentiated products and to support high wages. When this advantage was eroded, the United States had no other solution rather than lowering labor costs. Finally, in comparing the United States to Japan, they emphasized national savings trends as the root of enhancing national investment and by deduction the national productivity and living standards.

Since the 1990's, we have supported the development of a new theory of national competitiveness based on microeconomic foundations. This time, the theory was developed by a business strategy specialist who has served as an advisor on competitiveness to many countries, states, cities, and international companies, and is seen as a global authority on the subject matter (i.e Michael Porter). After developing the concept of a competitive strategy at the industry level [19] and the concept of competitive advantage of firms [20], Michael Porter completed his trilogy with the theory of the competitive advantage of nations [21]. He began his arguments with stressing the weakness of international trade theories and other economics theories to explain the specializations of firms in many nations. The theories of Smith to Samuelson were not enough for Porter to explain the international specialization of nations, because, they ignored the strategy at the firm level. Also, for Porter, asking if a nation is competitive or not the wrong question. For him, national productivity is at the root of the living standards. This was not new, since other economists have already tied the living standards with productivity. Porter's main idea is that productivity is sharpened by international trade and international investment of firms, and simulated by the race of firms to achieve their competitive advantage in a specific field. Thus, innovation is key to this effort, and Porter's main question was to understand why some companies based in some nations innovate more than others and why do some nations provide an environment that enables firms to innovate faster and better than their competitors? Thus, Porter defined the competitive advantage of a nation as its decisive characteristics that enables its companies to create and sustain a competitive advantage in particular sectors. As a measure of competitiveness Porter selected the country's share of world 
markets for its products, a measure that he later regretted because it takes international trade as a zero-sum game [22]. To sum up Porter's vision of competitiveness, we can say that, first, he emphasized the location, the micro-environment of firm as the field in which the competitive advantage is created and sustained [23], second, these dynamics are enhanced or damaged by the macroeconomic, political, legal, and social conditions.

Once again, many economists criticized this vision the competitiveness, linking international success of a country's firms with its national living standards. For instance, Paul Krugman criticized the national competitiveness concept on many occasions. He described competitiveness as a funny way to basically talk about productivity. For him, the hypothesis which links the living standards and competitiveness is wrong [24]. He illustrated this vision by an example of the US for which foreign trade is not relevant comparatively with the home activity. Thus, the living standards are not explained by foreign trade performance but by national productivity. Then, competitiveness is, indeed, nothing other than productivity. Also, as our classical foreign trade economists explained, for him, nations are in complementarity rather than in competition, and, foreign trade is a not a zero-sum game. Finally, he refuted the assumption under which nations compete and can be managed by the same way of managing firms [25].

By mixing and adapting all of these approaches, many international organizations have established their definition of competitiveness as a multifaceted and multi-approaches concept. For instance, in its Global Competitiveness Report of 2014-2015, the World Economic Forum (WEF) defined competitiveness as "the set of institutions, policies, and factors that determine the level of productivity of a country" [26]. As a measure, the WEF set 12 pillars of competitiveness which are the Institutions, Infrastructure, Macroeconomic environment, Health and primary education, Higher education and training, Goods market efficiency, Labor market efficiency, Financial market development, Technological readiness, Market size, Innovation and Business sophistication.

Finally, competitiveness authors continue to define other shapes of this concept, as the urban competitiveness [27], the regional competitiveness [28], and the institutional competitiveness [29], and continue to link it with other goals as the social cohesion [30].

\section{CONCLUSION}

Modern theories of national competitiveness forge this concept as a multifaceted and multi-approaches one.

It is important to assert that, even if one could think that modern authors, such as Michael Porter, have forged a new way of thinking about competitiveness, the ingredients of their vision already exist in classical economic theory. Whereas Smith, Ricardo, Mill, Marx, Engels, and other economists emphasized ingenuity, dexterity, productivity, communication, invention, innovation and so on, modern authors of competitiveness only focus on "cost". For instance, they see in Adam Smith's inquiry nothing but the "absolute advantage" - a concept that he doesn't actually discuss. Also, they "forget" that great economists, as Marx and Engels, have already emphasized the role of innovation and institutions in the competition power of firms rather than the cost approach Moreover, they "forget" the most important idea of the classical economists, that international trade is not a war between nations, or the main kind of competition. It's a complementarity and a win-win process. Finally, notwithstanding the ambiguity of the competitiveness' concept, linking it with the living standards can be hard work especially when we put in mind that the latter is also a concept which needs to be redefined [31].

This paper was a conceptual introduction to the concept of national competitiveness. The next stage will be an econometric test of the relevancy of the link between competitiveness components and living standards in the case of a panel of developing countries.

\section{REFERENCES}

[1] World Trade Organization (WTO), World Trade Report 2014: Trade and Development: Recent Trends and the Role of the WTO, Geneva: WTO, 2014.

[2] A. Smith, "An inquiry into the nature and causes of the wealth of nations, "Of the principle of the commercial, or mercantile system," in The Glasgow Edition of the Works and Correspondence, R. $\mathrm{H}$ Campbell, and A. S. Skinner, Eds. , vol. 2a, vol. 1, Oxford: Oxford University Press, p. 338-353, 1776.

[3] A. Smith, "An inquiry into the nature and causes of the wealth of nations, "Of the principle of the commercial, or mercantile system," in The Glasgow Edition of the Works and Correspondence, R. H. Campbell, and A. S. Skinner, Eds. , vol. 2a, vol. 1, Oxford: Oxford University Press, p. 341, 1976.

[4] A. Smith, "An inquiry into the nature and causes of the wealth of nations, 'Of the division of labour'," in The Glasgow Edition of the Works and Correspondence, R. H. Campbell and A. S. Skinner, Eds. vol. 2a, vol. 1, Oxford: Oxford University Press, p. 64-69, 1976.

[5] A. Smith, "An inquiry into the nature and causes of the wealth of nations, 'Of the division of labour'," in The Glasgow Edition of the Works and Correspondence, R. H. Campbell and A. S. Skinner, Eds. vol. 2a, vol. 1, Oxford: Oxford University Press, p. 66, 1976.

[6] R. Schumacher, "Adam Smith's theory of absolute advantage and the use of doxography in the history of economics," Erasmus Journal for Philosophy and Economics, vol. 5, issue 2, pp. 54-80, Autumn 2012.

[7] D. Ricardo, Principles of Political Economy and Taxation, in the Works and Correspondence of David Ricardo, 1817.

[8] J. S. Mill, "The silk trade," The Collected Works of John Stuart Mill, Volume IV - Essays on Economics and Society Part I, 1967, 1826.

[9] J. S. Mill, Principles of Political Economy: With Some of Their Applications to Social Philosophy, Hackett, Indianapolis/Cambridge, 2004.

[10] K. Marx, "On the question of free trade," Marx \& Engels Collected Works, vol. 06, 1848.

[11] F. Engels, "The free trade congress at brussels," Marx \& Engels Collected Works, vol. 6, 1847.

[12] P. Krugman, "Competitiveness: A dangerous obsession," Foreign Affairs, vol. 73, no. 2, March/April 1994.

[13] G. Wignaraja, Competitiveness Strategy in Developing Countries: A Manual for Policy Analysis, Routledge, London, 2003.

[14] P. R. Bergin and G. Corsetti, "International competitiveness and monetary policy: Strategic policy and coordination with a production relocation externality," National Bureau of Economic Research Paper, Working Paper No. 19356, Cambridge, August 2013.

[15] L. D. Tyson, "Creating advantage: Strategic policy for national competitiveness," Berkeley Roundtable on the International Economy, UC Berkeley, 1987.

[16] L. D. Tyson, Who's Bashing Whom? Trade Conflict in High-Technology Industries, Institute for International Economics, November 1992.

[17] G. L. Cowger, "Teaming for National competitiveness," Technology Transfer, Spring-Summer, 1992, pp. 34-39. 
[18] P. R. Krugman, G. N. Hatsopoulos, and L. H. Summers, "U.S. Competitiveness: Beyond the Trade Deficit," Sciences, vol. 241, pp. 299-307, 1988

[19] M. E. Porter, Competitive Strategy: Techniques for Analyzing Industries and Competitors, New York: Free Press, 1980.

[20] M. E. Porter, The Competitive Advantage: Creating and Sustaining Superior Performance, New York: Free Press, 1985.

[21] M. E. Porter, The Competitive Advantage of Nations, New York: Free Press, 1990.

[22] M. E. Porter, "Building the microeconomic foundations of prosperity: Findings from the business competitiveness index," The Global Competitiveness Report 2003-2004, Oxford University Press, 2004.

[23] M. E. Porter, "Location, competition, and economic development: Local clusters in a global economy," Economic Development Quarterly, vol. 14, no. 1, pp. 15-34, February 2000.

[24] P. Krugman, "Competitiveness: A Dangerous obsession," Foreign Affairs, vol. 73, no. 2, March/April 1994

[25] P. Krugman, "A Country is not a company," Harvard Business Review, pp. 40-51, January 1996.

[26] X. S. Martín, B. B. Osorio, A. D. Battista, M. D. Hanouz, T. Geiger, and C. Galvan, "The global competitiveness index 2014-2015 Accelerating a robust recovery to create productive jobs and support inclusive growth," The Global Competitiveness Report 2014-2015, World Economic Forum, Geneva, 2014.

[27] P. Ni, P. K. Kresl, and W. Liu, The Global Urban Competitiveness Report 2013, 2015.

[28] M. Kitson, R. Martin, and P. Tyler, "Regional competitiveness: An elusive yet key concept," Regional Studies, vol. 38, no. 9, pp. 991-999, December 2004.

[29] O. K. Pedersen, "Institutional competitiveness: How nations come to compete," Working paper no. 47, International Center for Business and Policies, 2008.

[30] E. Zoltan, "Relationship of competitiveness and social cohesion in the european union," Review of Social Sciences, vol. 1, 2016.

[31] J. E. Stiglitz, "The measurement of wealth: Recessions, sustainability and inequality," National Bureau Of Economic Research Paper, Working Paper No. 21327, New York, July, 2015.

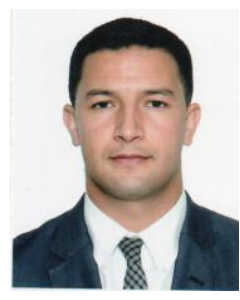

Yassine Ounnabi was born in Ouezzane, Morocco on 8 April, 1986. Ounnabi holds a bachelor degree in economics and management, attributed in 2007, by the University of Moulay Ismail in Meknès, Morocco. Two years later, from the same university, Ounnabi successfully completed a Master of Science in International Economics and Business. Then, Yassine Ounnabi moved to Rabat, the capital of Morocco, where he studied from 2010 to 2012 public management at the National Institute of Administration and was a visiting scholar at the Prestigious Ecole Nationale d'Administration in Paris, France. Currently, Ounnabi is preparing a Ph.D. dissertation on economic competitiveness and living standards at the University of Rabat-Souissi, Morocco.

At present, he works at the Office of Budget in the Moroccan Department of the Treasury in Rabat, Morocco, where he's in charge of The World Bank projects disbursements. In addition to his master thesis on Moroccan real exchange rate and exports and his work on performance-led dimension of the management of fiscal policy, he released a working paper, published in 2012 by the Ministry of Economic and Financial Affairs in Rabat, Morocco. That one has focused on the governance of foreign aid received by Morocco with respect to the Japanese International Cooperation Agency. His research interests deals with international macroeconomics, economic policy and the political economy of competitiveness.

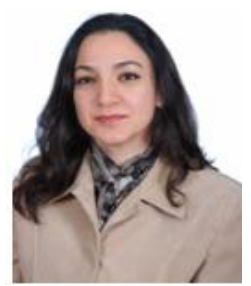

Lalla Latifa Alaoui is a permanent professor at the University of Mohammed Rabat-Souissi, Morocco. She holds a Master of Arts in International Economics and Business from the University of Rabat-Souissi, Morocco. In 2000, Alaoui successfully completed a $\mathrm{PhD}$ dissertation on the theory of the firm from the University of Rabat-Souissi, Morocco and obtained ten years later the Accreditation to Supervise Research from the same university. Meanwhile, she was awarded many certificates, the last one was discerned in 2013 by Intel on entrepreneurship.

Currently, she occupies simultaneously positions at the National School of Business Administration in Kenitra, Morocco and at the National Insitute of Statistics and Applied Economics in Rabat, Morocco, where she teaches undergraduate students international economics and personnal economics. Her last research addressed the the problematic of VAT and was published in 2006 by the International Review of Accounting. 